\title{
Impact of Capital Structure on Stock Prices: Evidence from Oman
}

\author{
Udayakumari Vidhyasagara Menon $^{1}$ \\ ${ }^{1}$ Dept. of Management Studies, Middle East College, Knowledge Oasis, Al Rusayl, Sultanate of Oman \\ Correspondence: Udayakumari Vidhyasagara Menon, Dept. of Management Studies, Middle East College, \\ Knowledge Oasis, Al Rusayl, Sultanate of Oman. E-mail: umenon@mec.edu.om
}

Received: April 21, 2016

doi:10.5539/ijef.v8n9p249
Accepted: August 20, 2016

Online Published: August 25, 2016

URL: http://dx.doi.org/10.5539/ijef.v8n9p249

\begin{abstract}
The study tests the relationship between capital structures and share prices of the listed companies of Muscat Securities Market (MSM). It considers all the 113 listed companies registered in MSM for three main sectors for a period of eight years i.e. 2008 till 2015. It analyzes the relationship between share price and capital structure by employing correlation analysis and multiple regression analysis in a panel framework. We found an inverse relationship between amount of debt and share prices. Further a positive relationship between amount of equity and share prices and debt equity ratio. The results were statistically significant at $1 \%$ level of significance. The results indicate adding debt to overall capital inversely effects the share prices. The results are in tandem to Net Income Approach which portrays capital structure to influence firm value.
\end{abstract}

Keywords: capital structure, debt, equity, firm value, muscat securities market, share price

\section{Introduction}

Share prices can be affected by a wide variety of factors with a predominance of performance of the company that has issued the shares and a much wider perspective where market forces are highly significant. Stock prices change on a daily basis as a result of these market forces. Influence of market forces can be easily explained by the idea that share prices change due to a change in the supply and demand for the company's shares. If more people are interested to buy than selling, demand for that particular share increases. In such a circumstance, the prices move up. Conversely, if more people want to sell a stock than buy it, there would be greater supply than demand, and the price would fall. Again the demand and supply may also be affected by the psychological factors of the investing public.

Further, it is also important to note that capital structure of the firm also influence its profitability to a great extent. Debt is a liability on which interest has to be paid irrespective of the company's profits. While equity consists of shareholders, or owners, funds on which payment of dividend depends upon the company's profits. A high proportion of debt content in the capital structure increases the risk and may lead to financial insolvency in adverse times. However, raising funds through debt is cheaper as compared to raising funds through shares. This is because interest on debt is allowed as an expense for tax purposes. Dividend is considered to be an appropriation of profits hence payment of dividend does not result in any tax benefit to the company. This means if a company, which is in the 50 percent tax bracket, pays interest at 12 percent on its debentures, the effective cost to it comes only to 6 percent. While if the amount is raised by issue of 12 percent preference shares, the cost of raising the amount would be 12 percent.

Thus, raising of funds by borrowing is cheaper resulting in higher profits for shareholders. This increases the earnings per equity share (EPS) of the company which is the basic objective of any investors. The choice of an appropriate capital structure depends on a number of factors, such as the nature of the company's business, regularity of earnings, conditions of the money market, attitude of the investor, etc. The companies should use a capital structure which also raises the worth of the company for its investors. This is an assumption used for the whole ideas of this research.

Therefore, a study on share price changes with the change in capital structure becomes highly significant. In the same line, this research also would look at; if a change in a capital structure may impact on the share prices. It can be simply by testing the changes in the debt or equity component they use in their capital, based on the above theories and assumptions. Thus, the research is presumed as will be a significant contribution to the corporate finance discipline. 


\section{Literature Review}

The relationship between capital structure and stock performance has been a growing area of management research. A comprehensive review of literature reveals that capital structure decisions were often subject to a large number of studies. It is an area in corporate finance which requires extensive planning skills and capital market exposure. If looking backward, several studies documented a significant decrease in the price of firms' common stock at the earliest public announcement of certain types of capital structure changes. As stated by Masulis (1978) there was a statistically significant negative average common stock return $\mathrm{s}$ at the announcement of intra firm exchange offers that involve the issuance of common stock for debt, common stock for preferred stock, or preferred stock for debt. In line with that, Mikkelson (1981) also has documented a very a considerable negative average common stock return at the announcement of convertible debt calls that force conversion of debt to common stock. Similarly the research works of Dann and Mikkelson (1984) and Korwar (1982) also had come up with similar findings of negative average return at the announcement of the issuance of convertible debt and common stock, respectively. None of these studies of capital structure changes, however, resolves the issue of what factors determine the negative average stock price response. Nor do they completely explain the motivation for these capital structure changes

As stated by Masulis (1983) presented an extensive theoretical literature available with respect to the optimal capital structure. However, evidence of a relation between changes in capital structure and firm value are seldom reported. However, Miller-Modigliani (1966) reported evidence of a positive relationship between firm value and leverage which they attributed to a debt tax shield effect. Even then, this result was doubtful due to the statistical problems they encountered when attempting to adjust for differences in the firms' asset structures. The study was considering only regulated firms and therefore, their empirical findings were caused by the regulatory environment in which these firms operate. Even after that study, no strong research work had been carried out to identify evidence of a relation between a firm's value and the size of its debt tax shield, evidence of a relation between a firm's value and the size of its debt tax shield. Further, Masulis (1983) found that both stock prices and firm values are positively related to changes in debt level and leverage; security prices are negatively related to these capital structure change variables. This evidence is consistent with models of optimal capital structure and with the hypothesis that debt level changes release information about changes in firm value.

Although significant literature exists on the issue of capital structure and stock market performance La Porta, et al., 2000; Iyer \& Agarwal, 2007; Strebuleav, 2007; Asquith \& Mullin, 1986; Baker \& Wurgler, 2002; Jung, Kim, \& Stulz, 1996; Mickelson \& Partch, 1989; Marsh, 1982; Dasgupta \& Hilary, 2006; Singal \& Mittal, 1993; Boodho, 2009; Mehmet \& Eda, 2009; Joshua, 2008; Fakher et al., 2005; Keshar \& Baral, 2004; Venkatesan, 1983; Asideu, 2005; Fama, 1998; Hutchinson, 1995; Singh, 2005) however limited research is available in context of Oman. Along with that empirical studies have yielded conflicting results. The current paper makes an attempt to fill the gap by study the relationship for the last eight years and showcases the impact of capital structure on the movement of share prices in context of listed companies in Oman.

\section{Research Objective}

This research tests the influence of changes in the debt and equity combination of the companies on the share prices of the listed companies of Muscat Securities Market. To bring strength for the analysis, all the listed companies were considered. There are 113 companies registered in MSM by the end of year 2015. To analyze the relationship between share price and capital structure the study identified the following three hypothesis

1) There exists an inverse relationship between amount of debt in a company and share prices.

2) There exists an positive relationship between amount of equity in a company and share prices.

3) There exists a positive relationship between debt/equity ratio and share prices.

\section{Research Methodology}

This research tests the influence of changes in the debt and equity combination of the companies on the share prices of the listed companies of Muscat Securities Market. To bring strength for the analysis, all the listed companies were considered. There are 113 companies registered in MSM by the end of year 2015. However the non-availability of share prices for all the companies related to all the relevant period restricted the scope to 41 companies out of the total 113 which is $36 \%$. It comprises 17 companies from Finance Sector, 12 from Service and 12 from Industrial sector. Also the companies which are listed in between the period of this study are also avoided, finally keeping the number of companies to 41. Data is collected from all the markets like regular, parallel, and third markets across all the sectors like Finance, Service and Industrial Sectors for the 5 years from 2008 to 2015, for these companies. The research has utilized secondary data to complete its analysis. The data 
regarding the capital structure and shares prices were collected from the published sources like the relevant companies' websites, Muscat Securities Market Website, investor's guide published by the MSM for the year 2015 etc. The share prices were downloaded from the MSM website. Capital structure; debt and equity combination details were collected from the company's annual reports as well as the financial reports downloaded from MSM website. These were also cross checked by the information available to the public through the investor's guide published by MSM.

\section{Econometric Methods}

Initially we explore the general properties of data using statistical tools like mean, standard deviation, kurtosis etc of the collected data. In the next stage we move one step ahead by studying the degree of correlation among the four variables by employing bivariate Pearson correlation method; the method calculates the pairwise associations for a set of variables and displays the results in a matrix. It is useful for determining the strength and direction of the association between variables.

Further, we analyze the relationship between share price and capital structure by employing a multiple linear regression model in a panel framework. We take share prices as dependent variable and the other three variables as independent variables. We also adopted stepwise regression model to check the robustness of our results for the full sample. It employs panel data framework (Note 1) for analysis work due to its advantage of allowing for more data points. Greene (1997) explained that the panel data sets allow researchers to capture both time series and cross-sectional relations. The basic panel data model is of the form:

$$
y_{i t}=\alpha_{0}+\beta_{0} * x_{i t}+\varepsilon_{i t}
$$

In equation (1), $y_{i t}$ is the dependent variable (Share Price); $\alpha_{o}$ is a constant; $x_{i t}$ is a $K$-dimensional vector of explanatory variables (Amount of Debt, Equity and Debt Equity Raio) and $\varepsilon_{\mathrm{it}}$ is the error term which is further decomposed into the following disturbance terms:

$$
\varepsilon_{i t}=\mu_{i t}+v_{i t}
$$

\section{Results}

In this paper, we tried to examine the influence of changes in the debt and equity combination of the companies on the share prices of the listed companies of Muscat Securities Market. In this section we discuss the empirical findings of the study. Table 1 presents the degree of correlation among the four variables by employing bivariate Pearson correlation method; the method calculates the pairwise associations for a set of variables and displays the results in a matrix. It is useful for determining the strength and direction of the association between variables.

Table 1. Pearson correlations for full sample period

\begin{tabular}{llllll}
\hline & & Share Price & Equity & Debt & De \\
\hline Share Price & Pearson Correlation & 1 & .000 & -.001 & $.224^{* *}$ \\
& Sig. (2-tailed) & & .999 & .987 & .003 \\
& $\mathrm{~N}$ & 215 & 215 & 179 & 179 \\
Equity & Pearson Correlation & .000 & 1 & $.861^{* *}$ & .130 \\
& Sig. (2-tailed) & .999 & & .000 & .083 \\
& $\mathrm{~N}$ & 215 & 215 & 179 & $.261^{* *}$ \\
\multirow{5}{*}{ Debt } & Pearson Correlation & -.001 & $.861^{* *}$ & 1 & .000 \\
& Sig. (2-tailed) & .987 & .000 & & 179 \\
& $\mathrm{~N}$ & 179 & 179 & 179 & 1 \\
& Pearson Correlation & $.224^{* *}$ & .130 & $.261^{* *}$ & .000 \\
\end{tabular}

**. Correlation is significant at the 0.01 level (2-tailed).

The results indicate a significant positive correlation between share price and debt equity ratio, amount of equity capital and debt and amount of debt and debt equity. The results also indicate negative correlation between equity share prices and amount of debt however the results are not statistically significant for the same. As pointed out in our earlier results which highlight differences among the three different sectors, we calculate correlation among the same variables for the three different sectors.

The results of correlation also reflect the differences among the four variables of our study among the different 
sectors (Table 2, $3 \& 4$ ). In case of financial sector, the relationship between share prices and amount of equity and debt is positive and the results are statistically significant, however the same relationship doesn't hold true for other two sectors.

Table 2. Pearson correlations for financial sector

\begin{tabular}{llllll}
\hline & & SP & Equity & Debt & DE \\
\hline SP & Pearson Correlation & 1 & $.310^{* *}$ & $.293^{* *}$ & .198 \\
& Sig. (2-tailed) & & .003 & .007 & .071 \\
\multirow{5}{*}{ Equity } & $\mathrm{N}$ & 90 & 90 & 84 & 84 \\
& Pearson Correlation & $.310^{* *}$ & 1 & $.988^{* *}$ & $.573^{* *}$ \\
& Sig. (2-tailed) & .003 & & .000 & .000 \\
\multirow{5}{*}{ Debt } & $\mathrm{N}$ & 90 & 90 & 84 & 84 \\
& Pearson Correlation & $.293^{* *}$ & $.988^{* *}$ & 1 & $.645^{* *}$ \\
& Sig. (2-tailed) & .007 & .000 & & .000 \\
& $\mathrm{~N}$ & 84 & 84 & 84 & 84 \\
\hline
\end{tabular}

Table 3. Pearson correlations for service sector

\begin{tabular}{|c|c|c|c|c|c|}
\hline & & SP & Equity & Debt & $\mathrm{DE}$ \\
\hline \multirow[t]{3}{*}{ SP } & Pearson Correlation & 1 & .041 & -.230 & .174 \\
\hline & Sig. (2-tailed) & & .743 & .065 & .166 \\
\hline & $\mathrm{N}$ & 65 & 65 & 65 & 65 \\
\hline \multirow[t]{3}{*}{ Equity } & Pearson Correlation & .041 & 1 & .117 & -.136 \\
\hline & Sig. (2-tailed) & .743 & & .352 & .279 \\
\hline & $\mathrm{N}$ & 65 & 65 & 65 & 65 \\
\hline \multirow[t]{3}{*}{ Debt } & Pearson Correlation & -.230 & .117 & 1 & .181 \\
\hline & Sig. (2-tailed) & .065 & .352 & & .149 \\
\hline & $\mathrm{N}$ & 65 & 65 & 65 & 65 \\
\hline \multirow[t]{3}{*}{ DE } & Pearson Correlation & .174 & -.136 & .181 & 1 \\
\hline & Sig. (2-tailed) & .166 & .279 & .149 & \\
\hline & $\mathrm{N}$ & 65 & 65 & 65 & 65 \\
\hline
\end{tabular}

Table 4. Pearson correlations for manufacturing sector

\begin{tabular}{llllll}
\hline & & SP & EQUITY & DEBT & DE \\
\hline SP & Pearson Correlation & 1 & -.065 & -.041 & -.013 \\
& Sig. (2-tailed) & & .620 & .755 & .921 \\
& $\mathrm{~N}$ & 60 & 60 & 60 & 60 \\
\multirow{5}{*}{ EQUITY } & Pearson Correlation & -.065 & 1 & -.120 & -.144 \\
& Sig. (2-tailed) & .620 & & .362 & .271 \\
& $\mathrm{~N}$ & 60 & 60 & 60 & 60 \\
& Pearson Correlation & -.041 & -.120 & 1 & $.630^{* *}$ \\
& Sig. (2-tailed) & .755 & .362 & & .000 \\
& $\mathrm{~N}$ & 60 & 60 & 60 & 60 \\
& Pearson Correlation & -.013 & -.144 & $.630^{* *}$ & 1 \\
& Sig. (2-tailed) & .921 & .271 & .000 & \\
& $\mathrm{~N}$ & 60 & 60 & 60 & 60 \\
\hline
\end{tabular}

**. Correlation is significant at the 0.01 level (2-tailed).

Surprisingly, we do not find any significant correlation between for service sector and in case of manufacturing sector we find evidence of negative correlation among the variables however the relationship is not statistically significant except for a single case.

\subsection{Results of Regression Analysis}

Further, we analyze the relationship between share price and capital structure by employing a multiple linear 
regression model. We take share prices as dependent variable and the other three variables as independent variables. We also introduce $\log$ of equity and debt as an additional variables. We have adopted stepwise regression model to check the robustness of our results for the full sample. The results are presented in Table 5-16. The ANOVA table tests the acceptability of the model from a statistical perspective. The p-value is less than 0.05 percent which indicates our model to be statistically significant. The same results are repeated for the other models when some variables were omitted.

Table 5. Results of ANOVA

\begin{tabular}{lllllll}
\hline ANOVA & \multicolumn{7}{c}{} & & \\
\hline Model & & Sum of Squares & $\mathrm{df}$ & Mean Square & $\mathrm{F}$ & Sig. \\
\hline 1 & Regression & 8.354 & 5 & 1.671 & 6.369 & $.000 \mathrm{a}$ \\
& Residual & 15.383 & 173 & .262 & & \\
& Total & 23.736 & 178 & & & $.000 \mathrm{~b}$ \\
2 & Regression & 8.354 & 4 & 2.088 & 8.007 & \\
& Residual & 15.383 & 174 & .261 & & $.000 \mathrm{c}$ \\
& Total & 23.736 & 178 & & & \\
& Regression & 8.280 & 3 & 2.760 & & \\
& Residual & 15.456 & 175 & .260 & & \\
& Total & 23.736 & 178 & & & \\
\hline
\end{tabular}

a. Predictors: (Constant), debt, de, loge, logd, equty;

b. Predictors: (Constant), debt, de, loge, equty;

c. Predictors: (Constant), debt, de, equty;

d. Dependent Variable: Share Price.

Table 6. Results of regression analysis

\begin{tabular}{|c|c|c|c|c|c|c|}
\hline \multicolumn{7}{|c|}{ Coefficientsa } \\
\hline \multirow[t]{2}{*}{ Model } & & \multicolumn{2}{|c|}{ Unstandardized Coefficients } & \multirow{2}{*}{$\begin{array}{c}\text { Standardized Coefficients } \\
\text { Beta }\end{array}$} & \multirow[t]{2}{*}{$\mathrm{t}$} & \multirow[t]{2}{*}{ Sig. } \\
\hline & & $\mathrm{B}$ & Std. Error & & & \\
\hline \multirow[t]{6}{*}{1} & (Constant) & .639 & .519 & & 1.230 & .220 \\
\hline & de & .028 & .008 & .304 & 3.348 & .001 \\
\hline & $\log d$ & $-7.257 \mathrm{E}-6$ & .064 & .000 & .000 & 1.000 \\
\hline & $\operatorname{loge}$ & -.055 & .155 & -.059 & -.356 & .722 \\
\hline & equty & $2.400 \mathrm{E}-6$ & .000 & .695 & 3.542 & .001 \\
\hline & debt & $-3.637 \mathrm{E}-7$ & .000 & -.645 & -3.939 & .000 \\
\hline \multirow[t]{5}{*}{2} & (Constant) & .639 & .451 & & 1.418 & .158 \\
\hline & de & .028 & .007 & .304 & 4.127 & .000 \\
\hline & loge & -.055 & .104 & -.059 & -.531 & .596 \\
\hline & equty & $2.400 \mathrm{E}-6$ & .000 & .695 & 3.869 & .000 \\
\hline & debt & $-3.637 \mathrm{E}-7$ & .000 & -.645 & -4.382 & .000 \\
\hline \multirow[t]{4}{*}{3} & (Constant) & .401 & .049 & & 8.118 & .000 \\
\hline & de & .029 & .007 & .305 & 4.153 & .000 \\
\hline & equty & $2.193 \mathrm{E}-6$ & .000 & .635 & 4.553 & .000 \\
\hline & debt & $-3.540 \mathrm{E}-7$ & .000 & -.628 & -4.382 & .000 \\
\hline
\end{tabular}

a. Dependent Variable: Share price.

Table 7. Model summary

\begin{tabular}{ccccccccr}
\hline Model & R & R Square & Adjusted R & Std. Error of the & \multicolumn{3}{c}{ Change Statistics } \\
\cline { 7 - 9 } & & & Square & Estimate & R Square Change & F Change & Sig. F Change \\
\hline dimension0 & 1 & .393 & .254 & .240 & .50966 & .154 & 10.626 & .000 \\
\hline
\end{tabular}


Table 8. Results of ANOVA model 2

\begin{tabular}{llccccc}
\hline Model & & Sum of Squares & df & Mean Square & F & Sig. \\
\hline 1 & Regression & 8.280 & 3 & 2.760 & 10.626 & $.000 \mathrm{a}$ \\
& Residual & 15.456 & 175 & .260 & & \\
& Total & 23.736 & 178 & & & \\
\hline
\end{tabular}

a. Predictors: (Constant), debt, de, equty;

b. Dependent Variable: Share price.

Table 9. Results of regression analysis full sample coefficients

\begin{tabular}{|c|c|c|c|c|c|c|}
\hline \multicolumn{2}{|c|}{ Model } & \multicolumn{2}{|c|}{ Unstandardized Coefficients } & \multirow{2}{*}{$\begin{array}{c}\text { Standardized Coefficients } \\
\text { Beta } \\
\end{array}$} & \multirow[b]{2}{*}{$\mathrm{t}$} & \multirow[b]{2}{*}{ Sig. } \\
\hline & & $\mathrm{B}$ & Std. Error & & & \\
\hline \multirow[t]{4}{*}{1} & (Constant) & .401 & .049 & & 8.118 & .000 \\
\hline & de & .029 & .007 & .305 & 4.153 & .000 \\
\hline & equity & $2.193 \mathrm{E}-6$ & .000 & .635 & 4.553 & .000 \\
\hline & debt & $-3.540 \mathrm{E}-7$ & .000 & -.628 & -4.382 & .000 \\
\hline
\end{tabular}

a. Dependent Variable: Share price.

Table 10. Results of regression analysis sector wise results, finance

\begin{tabular}{lllll}
\hline Dependent Variable: SP & & \\
\hline Model & $\mathrm{R}$ & R Square & Adjusted R Square & Std. Error of the Estimate \\
\hline 1 & $.325 \mathrm{a}$ & .105 & .072 & .3857927 \\
\hline
\end{tabular}

a. Predictors: (Constant), EQUITY, DE, DEBT.

Table 11. Results of ANOVA

\begin{tabular}{llccccc}
\hline Model & & Sum of Squares & df & Mean Square & F & Sig. \\
\hline 1 & Regression & 1.404 & 3 & .468 & 3.144 & $.030 \mathrm{a}$ \\
& Residual & 11.907 & 80 & .149 & & \\
& Total & 13.311 & 83 & & & \\
\hline
\end{tabular}

a. Predictors: (Constant), EQUITY, DE, DEBT;

b. Dependent Variable: SP.

Table 12 Results of regression analysis sector wise results, financial sector

\begin{tabular}{|c|c|c|c|c|c|c|}
\hline & & $\mathrm{B}$ & Std. Error & Beta & & \\
\hline \multirow[t]{4}{*}{1} & (Constant) & .165 & .085 & & 1.949 & .055 \\
\hline & DEBT & $-2.666 \mathrm{E}-7$ & .000 & -.890 & -.993 & .324 \\
\hline & $\mathrm{DE}$ & .019 & .023 & .138 & .828 & .410 \\
\hline & EQUITY & $2.223 \mathrm{E}-6$ & .000 & 1.107 & 1.325 & .189 \\
\hline
\end{tabular}

a. Dependent Variable: SP.

Table 13. Model summary, service sector

\begin{tabular}{ccccc}
\hline Model & $\mathrm{R}$ & $\mathrm{R}$ Square & Adjusted R Square & Std. Error of the Estimate \\
\hline 1 & $.335 \mathrm{a}$ & .112 & .068 & .7916563 \\
\hline
\end{tabular}

a. Predictors: (Constant), EQUITY, DEBT, DE.

Table 14. Results of ANOVA, service sector

\begin{tabular}{llccccc}
\hline Model & & Sum of Squares & df & Mean Square & F & Sig. \\
\hline 1 & Regression & 4.830 & 3 & 1.610 & 2.569 & $.062 \mathrm{a}$ \\
& Residual & 38.230 & 61 & .627 & & \\
& Total & 43.060 & 64 & & & \\
\hline
\end{tabular}

a. Predictors: (Constant), EQUITY, DEBT, DE;

b. Dependent Variable: SP. 
Table 15. Results of regression analysis sector wise results, service sector

\begin{tabular}{|c|c|c|c|c|c|c|}
\hline \multicolumn{2}{|c|}{ Model } & \multicolumn{2}{|c|}{ Unstandardized Coefficients } & \multirow{2}{*}{$\begin{array}{c}\text { Standardized Coefficients } \\
\text { Beta } \\
\end{array}$} & \multirow[b]{2}{*}{$\mathrm{t}$} & \multirow[b]{2}{*}{ Sig. } \\
\hline & & $\mathrm{B}$ & Std. Error & & & \\
\hline \multirow[t]{4}{*}{1} & (Constant) & .967 & .128 & & 7.532 & .000 \\
\hline & DEBT & $-7.300 \mathrm{E}-7$ & .000 & -.286 & -2.309 & .024 \\
\hline & $\mathrm{DE}$ & .022 & .011 & .240 & 1.933 & .058 \\
\hline & EQUITY & $6.976 \mathrm{E}-7$ & .000 & .108 & .876 & .385 \\
\hline
\end{tabular}

a. Dependent Variable: SP.

Table 16. Results of model summary, manufacturing sector

\begin{tabular}{ccccc}
\hline Regression & & & & \\
\hline Model & $\mathrm{R}$ & $\mathrm{R}$ Square & Adjusted R Square & Std. Error of the Estimate \\
\hline 1 & $.082 \mathrm{a}$ & .007 & -.046 & 1.9932794 \\
\hline
\end{tabular}

a. Predictors: (Constant), EQUITY, DEBT, DE.

Table 17. Results of ANOVA, manufacturing sector

\begin{tabular}{llccccc}
\hline Model & & Sum of Squares & df & Mean Square & F & Sig. \\
\hline 1 & Regression & 1.522 & 3 & .507 & .128 & $.943 \mathrm{a}$ \\
& Residual & 222.497 & 56 & 3.973 & & \\
& Total & 224.020 & 59 & & & \\
\hline
\end{tabular}

a. Predictors: (Constant), EQUITY, DEBT, DE;

b. Dependent Variable: SP.

Table 18. Results of regression analysis, manufacturing sector

\begin{tabular}{|c|c|c|c|c|c|c|}
\hline \multicolumn{2}{|c|}{ Model } & \multicolumn{2}{|c|}{ Unstandardized Coefficients } & \multirow{2}{*}{$\begin{array}{c}\text { Standardized Coefficients } \\
\text { Beta }\end{array}$} & \multirow[b]{2}{*}{$\mathrm{t}$} & \multirow[b]{2}{*}{ Sig. } \\
\hline & & $\mathrm{B}$ & Std. Error & & & \\
\hline \multirow[t]{4}{*}{1} & (Constant) & 1.132 & .398 & & 2.841 & .006 \\
\hline & DEBT & $-1.762 \mathrm{E}-6$ & .000 & -.058 & -.337 & .737 \\
\hline & $\mathrm{DE}$ & .040 & .524 & .013 & .077 & .939 \\
\hline & EQUITY & $-3.092 \mathrm{E}-6$ & .000 & -.070 & -.522 & .604 \\
\hline
\end{tabular}

a. Dependent Variable: SP.

Furthermore, the Regression row displays information about the variation accounted by our regression model and the residual row displays information about the variation that is not accounted for by your model. The residual sum of squares is quite high for our model, which indicates some movement is explained by some other unknown factors which we have not accounted for in the model.

The significance value of the F statistic is less than 0.05 , which means that the variation explained by the model is not due to chance. While the ANOVA table is a useful test of the model's ability to explain any variation in the dependent variable, it does not directly address the strength of that relationship. The model summary table reports the strength of the relationship between the model and the dependent variable.

The multiple correlation coefficients denoted by $\mathrm{R}$, shows that nearly $14 \%$ of the variation in share prices is explained by three factors taken in the model. Further, to determine the relative importance of the significant predictors, look at the standardized coefficients for Table 6 for the full sample period. The debt component contributes highest, followed by equity and then debt equity ratio to the overall predictability of the model because of their relative size of absolute standardized coefficients in the table.

Further, if we see the relationship between dependent and independent variables we see an inverse relationship between amount of debt and share prices. Further a positive relationship between amount of equity and share prices and debt equity ratio. The results are statistically significant at $1 \%$ level of significance. The results indicate adding debt to overall capital inversely effects the share prices. In the next stage we perform the same process for the three different sectors i.e. finance, service and manufacturing. In case of companies in the financial sector, service sector and manufacturing sector the inverse relationship holds true between amount of 
debt and share prices. However, the coefficients are larger for companies in financial sector indicating that borrowing through debt route leads to greater decline in stock prices for manufacturing sector as compared to other sectors.

\section{Discussion and Conclusion}

The influence of capital structure on firm value has been among the most debated topic in corporate finance. Several experts over the years have given different approaches which broadly can be classified into three broader categories i.e. Net Income Approach (which considered relevance of capital structure), Net Operating Income Approach (irrelevance of capital structure or capital structure having no impact on firm value) and Traditional Approach which was a combination of first two approaches. Further, Modigliani and Miller (1958) also as sumed markets to be perfect and absence of taxes, transaction cost etc and therefore anticipated that proportion of debt-equity did not had any significant impact on the value of the firm. In 1963, Modigliani and Miller gave a new theory which relaxed the assumption of no taxes and explained that the value of the firm or cost of capital varied with the variation in the utilization of debt capital due to tax benefits (Baral, 1996). MM considered the corporate taxes and concluded that due to tax deductibility of interest; the use of debt increases the value of the firm. Along with that other theories like the static trade-off, the pecking order theory, signalling theory and the agency theory came into existence in the same context.

The study was an attempt in the same direction and tried to establish a link between capital structure and firm value in Muscat Securities Market. Along with that the study also examined the level of systemic risk and their covariation with respect to Muscat stock Index and individual companies listed on the exchange. The study has attempted to answer these specific questions by taking into account secondary data available on the exchange website.

After studying the relationship between share prices and capital structure we see an inverse relationship between amount of debt and share prices. Further a positive relationship between amount of equity and share prices and debt equity ratio. The results were statistically significant at $1 \%$ level of significance. The results indicate adding debt to overall capital inversely effects the share prices. The results are in tandem to Net Income Approach which portrays capital structure to influence firm value.

Further, the result also indicates negative perception of investors towards increase in debt and therefore the market prices decline with the increase in debt. When we explored the same relationship across three different sectors i.e. finance, service and manufacturing sector we found in case of companies in the financial sector, service sector and manufacturing sector the inverse relationship holds true between amount of debt and share prices. However, the coefficients are larger for companies in financial sector indicating that borrowing through debt route leads to greater decline in stock prices for manufacturing sector as compared to other sectors.

These findings have important implications for managers or people who take decisions regarding capital structure. The changes in capital structure may have a significant impact on stock prices of the companies in context of Oman. Therefore, the decisions regarding capital structure should be taken with care so that there is no negative impact on firm value.

\section{References}

Abor, J. (2008). Determinants of the capital structure of Ghanaian firms. Department of Finance University of Ghana business school legion.

Baltagi, B. H. (2005). Econometric Analysis of Panel Data (3rd ed.). John Wiley \& Sons Ltd.

Baral, K. J. (2004). Determinants of capital structure: A case study of listed companies of Nepal. The Journal of Nepalese Business Studies.

Boodhoo, \& Roshan. (2009). Capital Structure and Ownership Structure: A Review Literature. The Journal of Online Education, New York.

Dann, L. Y., \& Wayne, H. M. (1984). Convertible debt issuance, capital structure change and financing-related information: Some new evidence. Journal of Financial Economics, 13, 157-186. http://dx.doi.org/10.1016/0304-405X(84)90022-9

Jenson, M. C. (1986). Agency coasts of free cash flow, corporate finance and take over. American Economic Review, 76, 323-339.

Jenson, M., \& Meckling, W. (1976). Theory of the firm: Managerial behaviour agency cost, and ownership structure. Journal of Financial Economic, 3, 305-360. http://dx.doi.org/10.1016/0304-405X(76)90026-X 
Kale, K. M., \& Walking, R. A. (1996). The impact of industry classifcation on financial research. Journal of Financial and Quantitative Analysis, 31, 309-355. http://dx.doi.org/10.2307/2331394

Korwar, A. N. (1982). The effect of new issues of equity. University of California.

Lev, B. (1974). On the association between operating leverage and risk. Journal of Financial Quantities Analysis, 627-641. http://dx.doi.org/10.2307/2329764

Masulis, R. W. (1983). The impact of capital structure change on firm value: Some estimates. The Journal of Finance, 38(1), 107-126. http://dx.doi.org/10.1111/j.1540-6261.1983.tb03629.x

Mickelson, W., \& Patrch, M. (1989). Managers voting rights and corporate control. Journal of Financial Economics, 25, 263-1990. http://dx.doi.org/10.1016/0304-405X(89)90084-6

Modigliani, F., \& Merton, H. M. (1958). The cost of capital, corporation finance and the theory of investment. The American Economic Review, 261-297.

Peterson, M. A., \& Rajan, R. G. (1994). The benefts of lending relationship: Evidence from small business data. The Journal of Finance, 49(1), 3-38. http://dx.doi.org/10.1111/j.1540-6261.1994.tb04418.x

Singal, R. K., \& Mittal, R. K. (1992). Determinants of capital structure: A survey. Finance India, 7(4), 883-889.

Stebuleavilya, A. (2007). Do test of capital structure theory mean what they say? Journal of Finance, 62, 1747-1787. http://dx.doi.org/10.1111/j.1540-6261.2007.01256.x

\section{Copyrights}

Copyright for this article is retained by the author(s), with first publication rights granted to the journal.

This is an open-access article distributed under the terms and conditions of the Creative Commons Attribution license (http://creativecommons.org/licenses/by/4.0/). 